\title{
GAMBARAN TINGKAT KECEMASAN PADA PASIEN STROKE DI RUANG BELIBIS RSUD WANGAYA DENPASAR
}

\author{
Suputra, Dewa Ketut ${ }^{1}$; Muryani, Ni Made $\operatorname{Sri}^{2 *}$; Sukarja, I Made ${ }^{3}$; Krisnayani, Ni \\ Made Wina ${ }^{4}$ \\ ${ }^{1,2,4}$ Akademi Keperawatan Kesdam IX/Udayana \\ ${ }^{3}$ Politeknik Kesehatan Denpasar \\ "Korespondensi: srimuryanimade@ @mail.com
}

\begin{abstract}
Background: Stroke is a major cause of disability in adults, where four million Americans experience neurological deficits due to stroke, two-thirds of these deficits are moderate to severe. This disease has become a worldwide health problem and is increasingly important, with two-thirds of strokes now occurring in developing countries. Stroke sufferers themselves will experience a psychological response, namely anxiety because in addition to being a life threat, patients will feel anxious about their future. The purpose of this study was to determine the description of the level of anxiety in stroke patients in the Belibis Room of Wangaya Hospital Denpasar. Methode: The type of design used is descriptive design. Data collection was carried out by the researchers themselves using a standard questionnaire sheet, the Hamilton Anxiety Rating Scale (HARS), with the number of respondents 30 people who were Stroke patients in the Belibis room of Wangaya Hospital Denpasar. Result: The results of this study indicate that the majority of stroke patients in the Belibis room of Wangaya Hospital Denpasar experienced moderate anxiety, namely as many as $17(56.7 \%)$ respondents, mild anxiety as many as $6(20 \%)$ respondents, severe anxiety as many as $6(20 \%)$ respondents, panic $0 \%$, and only $1(3.3 \%)$ respondents who did not experience anxiety. Conclusion: Individuals who experience anxiety are mostly aged over 50 years, female sex, high school education, and have private jobs. It is expected that families can provide motivation and positive encouragement to patients.
\end{abstract}

Keywords: Anxiety Level; Stroke Patients

\begin{abstract}
ABSTRAK
Latar Belakang: Stroke adalah penyebab utama kecacatan pada orang dewasa, dimana empat juta orang Amerika mengalami defisit neurologik akibat stroke, dua pertiga dari defisit ini bersifat sedang sampai parah. Penyakit ini telah menjadi masalah kesehatan yang mendunia dan semakin penting, dengan dua pertiga stroke sekarang terjadi di negara - negara yang sedang berkembang. Penderita stroke sendiri akan mengalami suatu respon psikologis, yaitu kecemasan karena selain menjadi
\end{abstract}


suatu ancaman hidup, pasien akan merasa cemas akan masa depannya. Tujuan penelitian ini untuk mengetahui Gambaran Tingkat Kecemasan Pada Pasien Stroke di ruang Belibis RSUD Wangaya Denpasar. Metode: Jenis desain yang digunakan adalah desain deskriptif. Pengumpulan data dilakukan oleh peneliti sendiri dengan menggunakan lembar kuesioner yang sudah baku yaitu Hamilton Anxiety Rating Scale (HARS), dengan jumlah responden 30 orang yang merupakan pasien Stroke di ruang Belibis RSUD Wangaya Denpasar. Hasil: Hasil penelitian ini menunjukkan bahwa sebagian besar penderita stroke di ruang Belibis RSUD Wangaya Denpasar mengalami kecemasan sedang, yaitu sebanyak 17 responden $(56,7 \%)$, kecemasan ringan sebanyak 6 orang (20\%), kecemasan berat sebanyak 6 orang $(20 \%)$, panik $0 \%$, dan hanya 1 orang $(3,3 \%)$ responden yang tidak mengalami kecemasan. Simpulan: Individu yang mengalami kecemasan sedang sebagian besar berusia diatas 50 tahun, jenis kelamin perempuan, pendidikan SMA, dan memiliki pekerjaan swasta. Diharapkan keluarga mampu memberikan motivasi dan dorongan positif pada pasien.

Kata Kunci : Tingkat Kecemasan; Pasien Stroke

\section{PENDAHULUAN}

Kecemasan (ansietas) adalah respon psikologik terhadap stress yang mengandung komponen fisiologik dan psikologik. Manifestasi yang khas pada

ansietas tergantung pada masing-masing individu dan dapat meliputi menarik diri, membisu, mengumpat, mengeluh, dan menangis (Long, 1996).

Stroke adalah penyebab cacat nomor satu dan penyebab kematian nomor dua di dunia. Penyakit ini telah menjadi masalah kesehatan yang mendunia dan semakin penting, dengan dua pertiga stroke sekarang terjadi di negara - negara yang sedang berkembang. Sekitar 13 juta korban stroke baru setiap tahun, di mana sekitar 4,4 juta di antaranya meninggal dalam 12 bulan. Terdapat sekitar 250 juta anggota keluarga yang berkaitan dengan para pengidap stroke yang bertahan hidup. Selama perjalanan hidup mereka, sekitar empat dari lima keluarga akan memiliki salah seorang anggota mereka yang terkena stroke ( Valery, 2004).

Menurut Data Dinas Kesehatan Propinsi Bali, jumlah pasien yang menderita penyakit kardiovaskuler dan stroke pada tahun 2008 mencapai 5.172 orang, tahun 2009 mencapai 3.166 orang, tahun 2010 mencapai 7090 orang, dan pada tahun 2011 mencapai angka 3.745 orang. Jumlah pasien stroke mencapai 6,7\% dari jumlah penderita penyakit kardiovaskuler yaitu 2.890 jiwa dan sekitar $20 \%$ dari pasien meninggal dunia, atau mengalami kecacatan. 
RSUD Wangaya Denpasar memiliki kamar rawat inap untuk pasien khusus stroke atau stroke unit. Khusus penderita stroke didapatkan data kejadian yang sangat tinggi yaitu 207 kasus pasien stroke pada tahun 2010, dan meningkat pada tahun 2011, yaitu sebanyak 250 kasus yang terdiri dari 192 kasus stroke non hemoraghic atau stroke tanpa perdarahan dan 265 kasus stroke hemoraghic atau stroke perdarahan. Data kematian dari kasus diatas yaitu 7 pasien stroke tanpa perdarahan dan 45 pasien stroke perdarahan.

Mengingat penyakit stroke adalah penyakit yang sangat berbahaya dan dapat mengancam nyawa, maka pasien stroke akan mengalami respon psikologis, salah satunya adalah kecemasan. Cemas adalah keadaan dimana seseorang mengalami perasaan gelisah dan aktivitas saraf otonom dalam berespon terhadap ancaman yang tidak jelas, tidak spesifik (Carpernito, 2000).

Berdasarkan studi pendahuluan yang dilakukan pada 5 orang penderita stroke di Ruang Belibis RSUD Wangaya Denpasar pada tanggal 25 Januari 2012, dengan metoda wawancara didapatkan 20\% mengalami kecemasan kategori ringan, 60\% mengalami kecemasan kategori sedang, dan 20\% mengalami kecemasan kategori berat. Hasil tersebut menunjukkan adanya kecemasan yang signifikan pada penderita stroke.

Kecemasan juga merupakan hal yang umum terjadi pada klien yang mengalami sakit serta di hospitalisasi, termasuk pada pasien stroke. Adanya suatu penyakit yang serius dan kronis, dan salah satunya adalah stroke pada diri seseorang, dapat mengakibatkan terjadinya kecemasan karena adanya proses pengobatan yang lama yang akan menyebabkan kecemasan pada diri penderita. Kecemasan dapat terjadi pada penderita stroke dikarenakan kurangnya pengetahuan tentang penyakitnya yang akhirnya mengakibatkan kondisi penderita menjadi perasaan tak berdaya, yang di wujudkan dengan menangis, marah, menarik diri, dan perasaan tidak ada harapan (Doengoes, 2000).

Rata-rata klien post stroke membutuhkan waktu yang lama untuk memulihkan dan memperoleh fungsi penyesuaian diri secara maksimal atau mempersiapkan penderita cacat secara fisik, mental, sosial, untuk suatu kehidupan yang penuh sesuai 
dengan kemampuan yang ada, untuk itu klien post stroke membutuhkan program rehabilitasi (Okti, 2004). Berdasarkan latar belakang tersebut, peneliti tertarik untuk meneliti tentang gambaran tingkat kecemasan pada pasien stroke. Tujuan penelitian ini adalah untuk menggambarkan tingkat kecemasan pada pasien stroke di Ruang Belibis RSUD.Wangaya

\section{METODE}

Penelitian ini merupakan penelitian kuantitatif dengan metode deskriptif. Populasi dalam penelitian ini adalah pasien stroke di ruang Belibis, RSUD Wangaya Denpasar. Cara pengambilan sampel dengan tehnik consecutive sampling, dengan jumlah sampel 30 responden. Kriteria inklusi dalam penelitian adalah klien yang mau dijadikan responden, klien yang telah didiagnosa oleh dokter dengan diagnosa stroke, klien yang masih bisa berkomunikasi, klien yang tidak memiliki penyakit penyerta (jantung, DM). Kriteria eksklusi adalah klien yang tiba-tiba mengalami penurunan kesadaran dan klien yang dalam keadaan atau kondisi memburuk.

Instrumen yang digunakan untuk mengumpulkan data adalah dengan menggunakan instrumen kuesioner yang sudah baku. Instrumen tersebut mencakup gejala kecemasan yang dikenal dengan nama Hamilton Rating Scale for Anxiety (HRS-A). Alat ukur ini terdiri dari 14 kelompok gejala yang masing-masing kelompok di rinci lagi dengan gejala-gejala yang lebih spesifik. Masing-masing kelompok gejala diberi penilaian angka (Score) antara 0-4. Skor kurang dari 14 adalah tidak ada cemas, skor 14-20 adalah kecemasan ringan, skor 21-27 adalah kecemasan sedang, skor 28-41 adalah kecemasan berat, dan skor 42-56 adalah kecemasan berat sekali/ panik. 


\section{HASIL}

Tabel 1 Karakteristik Pasien Stroke di Ruang Belibis RSUD.Wangaya

\begin{tabular}{ccc}
\hline Karakteristik & Jumlah (n) & Presentase (\%) \\
\hline Umur (tahun) & 0 & 0 \\
$13-20$ & 0 & 0 \\
$21-30$ & 0 & 0 \\
$31-40$ & 5 & 16.60 \\
$41-50$ & 25 & 83.40 \\
$>50$ & & \\
Jenis Kelamin & 16 & 53.30 \\
Laki-Laki & 14 & 46.70 \\
Perempuan & & \\
Pendidikan & 3 & 10 \\
SD & 4 & 13.20 \\
SLTP & 8 & 26.70 \\
SMA & 5 & 16.70 \\
Diploma & 5 & 16.70 \\
Perguruan Tinggi & 5 & 16.70 \\
Tidak Sekolah & & \\
Pekerjaan & 5 & 16.60 \\
Tidak Bekerja & 17 & 56.70 \\
Swasta & 8 & 26.70 \\
POLRI/PNS/TNI & &
\end{tabular}

Tabel 1 menunjukkan sebagian besar responden berusia diatas 50 tahun sebanyak $25(83.40 \%)$ responden. Sebagian besar berjenis kelamin laki-laki sebanyak $16(53.33 \%)$. Pendidikan responden sebagian besar pendidikan SMA sebanyak 8 (26.70\%) responden, dan $17(56.70 \%)$ respon memiliki pekerjaan swasta.

Tabel 2 Gambaran Kecemasan Pasien Stroke di Ruang Belibis RSUD.Wangaya

\begin{tabular}{ccc}
\hline Tingkat HDR & Jumlah $(\mathbf{n})$ & Presentase $(\%)$ \\
\hline Tidak ada kecemasan & 1 & 3.30 \\
Kecemasan ringan & 6 & 20 \\
Kecemasan sedang & 17 & 56.70 \\
Kecemasan berat & 6 & 20 \\
Panik & 0 & 0 \\
\hline
\end{tabular}

Tabel 2 menunjukkan sebagian besar responden mengalami kecemasan sedang sebanyak 17 (56.70\%) responden. Kecemasan ringan dan berat sebanyak 6 (20\%) responden, tidak cemas 1 (3.30) responden dan tidak ada responden yang mengalami panic. 
Tabel 3 Gambaran Kecemasan Pasien Stroke di Ruang Belibis RSUD.Wangaya Berdasarkan Karakteristik

\begin{tabular}{|c|c|c|c|c|c|c|c|c|c|c|c|c|}
\hline \multirow{2}{*}{ Karakteristik } & \multicolumn{2}{|c|}{$\begin{array}{l}\text { Tidak } \\
\text { Cemas }\end{array}$} & \multicolumn{2}{|c|}{ Ringan } & \multicolumn{2}{|c|}{ Sedang } & \multicolumn{2}{|c|}{ Berat } & \multicolumn{2}{|c|}{ Panik } & \multicolumn{2}{|c|}{ Total } \\
\hline & n & $\%$ & $\mathbf{n}$ & $\%$ & n & $\%$ & n & $\%$ & $\mathbf{n}$ & $\%$ & $\mathbf{n}$ & $\%$ \\
\hline \multicolumn{13}{|l|}{ Umur (tahun) } \\
\hline $13-20$ th & 0 & 0 & 0 & 0 & 0 & 0 & 0 & 0 & 0 & 0 & 0 & 0 \\
\hline $21-30$ th & 0 & 0 & 0 & 0 & 0 & 0 & 0 & 0 & 0 & 0 & 0 & 0 \\
\hline $31-40$ th & 0 & 0 & 0 & 0 & 0 & 0 & 0 & 0 & 0 & 0 & 0 & 0 \\
\hline $41-50$ th & 0 & 0 & 1 & 3.30 & 3 & 10 & 1 & 3.30 & 0 & 0 & 5 & 16.67 \\
\hline$>50$ th & 1 & 3.3 & 5 & 16.7 & 14 & 46.70 & 5 & 16.70 & 0 & 0 & 25 & 83.33 \\
\hline \multicolumn{13}{|l|}{ Jenis Kelamin } \\
\hline Laki-laki & 0 & 0 & 6 & 20 & 7 & 23.40 & 3 & 10 & 0 & 0 & 16 & 53.33 \\
\hline Perempuan & 1 & 3.3 & 0 & 0 & 10 & 33.30 & 3 & 10 & 0 & 0 & 14 & 46.67 \\
\hline \multicolumn{13}{|l|}{ Pendidikan } \\
\hline $\mathrm{SD}$ & 0 & 0 & 0 & 0 & 2 & 6.70 & 1 & 3.30 & 0 & 0 & 3 & 10 \\
\hline SMP & 1 & 3.3 & 0 & 0 & 1 & 3.30 & 2 & 6.70 & 0 & 0 & 4 & 13.20 \\
\hline SMA & 0 & 0 & 2 & 6.70 & 5 & 16.80 & 1 & 3.30 & 0 & 0 & 8 & 26.70 \\
\hline Diploma & 0 & 0 & 1 & 3.30 & 3 & 10 & 1 & 3.30 & 0 & 0 & 5 & 16.67 \\
\hline Perguruan Tinggi & 0 & 0 & 2 & 6.70 & 3 & 10 & 0 & 0 & 0 & 0 & 5 & 16.67 \\
\hline Tidak sekolah & 0 & 0 & 1 & 3.30 & 3 & 10 & 1 & 3.30 & 0 & 0 & 5 & 16.67 \\
\hline \multicolumn{13}{|l|}{ Pekerjaan } \\
\hline Tidak bekerja & 0 & 0 & 1 & 3.30 & 3 & 10 & 1 & 3.30 & 0 & 0 & 5 & 16.60 \\
\hline Swasta & 1 & 3.3 & 3 & 10 & 8 & 26.60 & 5 & 16.80 & 0 & 0 & 17 & 56.70 \\
\hline PNS/POLRI/TNI & 0 & 0 & 2 & 6.70 & 6 & 20 & 0 & 0 & 0 & 0 & 8 & 26.70 \\
\hline
\end{tabular}

Tabel 3 menunjukkan berdasarkan umur lebih banyak responden mengalami kecemasan sedang pada usia diatas 50 tahun sebanyak 14 (46.70\%). Jenis kelamin perempuan lebih banyak mengalami kecemasan sedang sebanyak 10 (33.30\%). Responden yang memiliki pendidikan SMA mengalami kecemasan sedang sebanyak $5(16.80 \%)$. Kecemasan sedang lebih banyak dialami oleh responden yang memiliki pekerjaan swasta.

\section{PEMBAHASAN}

\section{Gambaran Tingkat Kecemasan Pasien Stroke}

Hasil penelitian ini menunjukkan bahwa sebagian besar responden, yaitu 17 $(56.70 \%)$ responden mengalami kecemasan dalam kategori sedang, dan 6 (20\%) responden mengalami kecemasan berat, 6 (20\%) responden mengalami kecemasan ringan, dan $1(3,3 \%)$ responden yang tidak mengalami kecemasan. 
Rendahnya presentase yang mengalami kecemasan berat, berkaitan dengan karakteristik seperti umur, jenis kelamin, pendidikan, maupun pekerjaan responden. Sebagian besar responden mengalami kecemasan berusia $>50$ tahun, dan berpendidikan SMA. Dari gambaran hasil penelitian yang dilaksanakan, kematangan usia dan pendidikan sangat berpengaruh terhadap seseorang dalam menyikapi situasi atau penyakit pada dirinya dalam mengatasi kecemasan yang di alami (Nursalam, 2003).

Kecemasan merupakan suatu respon psikologis dan fisiologis, perasaan takut/ tidak tenang yang sumbernya tidak diketahui (Barbara C. Long, 2001). Kecemasan dapat terjadi pada penderita stroke dikarenakan kurangnya pengetahuan tentang penyakitnya yang akhirnya mengakibatkan kondisi penderita menjadi perasaan tak berdaya, yang diwujudkan dengan menangis, marah, menarik diri, dan perasaan tidak ada harapan (Doengoes, 2000).

Upaya yang telah dilakukan oleh perawat di ruang Belibis RSUD Wangaya Denpasar dalam mengatasi kecemasan pada pasien stroke adalah menjalin komunikasi terapeutik yang diharapkan akan mengurangi rasa cemas dan mempercepat penyembuhan pada pasien stroke. Selain itu informasi yang sering diberikan kepada masyarakat adalah melalui penyuluhan tentang melakukan pola hidup sehat dan menghentikan kebiasaan merokok.

\section{Tingkat Kecemasan Berdasarkan Karakteristik}

Kategori kecemasan sedang paling tinggi presentasenya, yaitu pada umur $>50$ tahun sebanyak 14 orang $(46,70 \%)$, dan presentase yang paling sedikit yaitu pada umur 41-50 tahun sebanyak 3 orang (10\%). Hal ini menggambarkan bahwa tingkat kecemasan yang sebagian besar dialami yaitu pada umur $>50$ tahun. Berdasarkan penelitian ini, menunjukkan bahwa usia merupakan salah satu faktor yang mempengaruhi tingkat kecemasan pada pasien stroke di ruang Belibis RSUD Wangaya Denpasar, sehingga dukungan keluarga sangat diperlukan dalam hal ini untuk mengurangi kecemasan klien. Klien yang khususnya berumur $>50$ tahun akan merasa cemas bahwa klien mungkin akan menjadi tergantung kepada anak dan keluarganya, sehingga klien mungkin terancam oleh perasaan takut hidup tergantung 
kepada anak dan keluarga dan akan menjadi beban keluarganya (Mark H. Swartz, 1995).

Berdasarkan karakteristik jenis kelamin dari kategori kecemasan sedang paling tinggi presentasenya, yaitu pada perempuan sebanyak $10(33.30 \%)$ responden, dan presentase yang paling sedikit yaitu pada laki-laki sebanyak 7 (23.40\%) responden. Kategori kecemasan berat, terdapat presentase yang sama, yaitu pada lakilaki sebanyak 3 orang (10\%), dan pada perempuan sebanyak 3 orang (10\%). Hal ini menunjukkan bahwa laki-laki lebih mudah merasakan kecemasan daripada perempuan, ini disebabkan karena pada masa masih produktif untuk bekerja laki-laki lebih takut untuk kehilangan kedudukan atau jabatan yang mungkin prestisius, sehingga takut akan tidak bisa berkarya lagi, dari hal inilah akan menimbulkan suatu respon psikologis yaitu respon kecemasan (Mark H. Swartz, 1995).

Berdasarkan karakteristik pendidikan dari kategori kecemasan sedang paling tinggi presentasenya, yaitu pada tingkat pendidikan SMA sebanyak 5 (16.80\%) responden, dan presentase yang paling sedikit yaitu pada tingkat pendidikan SMP sebanyak $1(3.30 \%)$ responden. Kategori kecemasan berat, paling tinggi presentasenya yaitu pada tingkat pendidikan SMP sebanyak $2(6.70 \%)$ responden. Pendidikan sangatlah berpengaruh terhadap tingkat kecemasan. Seseorang yang mengenyam pendidikan minimal sampai sekolah menengah atas, pasti akan mengerti akan apa yang akan terjadi jika telah menderita penyakit stroke, selain kecacatan, pasien juga cemas akan kematian. Hal ini juga selaras dengan pendapat Horney (1994), yang mengatakan bahwa faktor kognitif merupakan salah satu faktor penyebab terjadinya kecemasan. Kognitif atau tingkat pengetahuan sangat erat kaitannya dengan tingkat pendidikan seseorang. Faktor belajar juga sangat erat dengan pendidikan.

Berdasarkan karakteristik pekerjaan dari kategori kecemasan sedang paling tinggi presentasenya, yaitu pada pekerjaan swasta sebanyak $8(26.60 \%)$ responden, dan presentase yang paling sedikit yaitu pada pekerjaan tidak bekerja sebanyak 3 orang $(10 \%)$. Dari kategori kecemasan berat, paling tinggi presentasenya yaitu pada pekerjaan swasta sebanyak $5(16.80 \%)$ responden. Pengusaha swasta sangat tinggi 
yang mengalami kecemasan, dikarenakan ketakutan akan ketidakmampuan untuk mengurus usaha yang telah di rintis bertahun-tahun, atau bahkan cemas akan mengalami kebangkrutan. Jenis pekerjaan akan banyak mempengaruhi kecemasan seseorang dan mempengaruhi kematangan seseorang dalam mengatasi masalah. Pria muda yang mempunyai kedudukan atau jabatan pekerjaan yang mengalami atau menderita penyakit jantung akan merasa tidak berdaya dan cemas akan kehilangan kedudukan atau jabatannya (Mark H. Swartz, 1995).

\section{SIMPULAN DAN SARAN}

Hasil penelitian ini menunjukkan sebagian besar responden mengalami kecemasan sedang. Individu yang mengalami kecemasan sedang sebagian besar berusia diatas 50 tahun, jenis kelamin perempuan, pendidikan SMA, dan memiliki pekerjaan swasta. Diharapkan keluarga yang merupakan orang terdekat mampu memberikan motivasi dan dorongan positif agar pasien tidak kehilangan semangat dan dapat mengurangi kecemasan pada klien, sehingga kondisi pasien tetap stabil, dan pasien mampu menggunakan mekanisme koping yang positif.

\section{DAFTAR PUSTAKA}

Carpernito. (2000). Buku Saku Diagnosa Keperawatan, Edisi 8. Jakarta: EGC.

Doengoes, M.,dkk. (2000). Rencana Asuhan Keperawatan \& Pedoman Untuk Perencanaan dan Pendokumentasian Perawatan Pasien. Edisi III. Jakarta: EGC

Horney. (1994). Penyebab Kecemasan (online). Tersedia di: http//www.penyebab kecemasan dan pengaruhnya/kepribadian.co.id

Long, Barbara C.(1996). Praktek Perawatan Medikal Bedah ( Suatu Pendekatan Proses Keperawatan ). Bandung: Yayasan Alumni Pendidikan Keperawatan

Long, B. C. (2001). Keperawatan Medikal Bedah, Edisi dua, alih bahasa Yayasan Ikatan Alumni pendidikan Keperawatan Universitas Padjajaran Bandung.

Nursalam. (2003). Konsep \& Penerapan Metodologi Penelitian Ilmu Keperawatan. Jakarta: Salemba Medika

Okti. S.P. (2004). Kepatuhan Klien Post Stroke dalam Melaksanakan Mobilisasi Dini di Ruang Rawat Inap Rumah Sakit Umum Daerah Purworejo, Skripsi tidak diterbitkan, Program Studi Ilmu Keperawatan Universitas Gajah Mada, Yogyakarta. 
Swartz, M, H. (1995). Buku Ajar Diagnostik Fisik, Buku 1. Jakarta: Penerbit Buku Kedokteran EGC

Valery. F. (2002). Stroke, Cetakan Kedua. Jakarta: PT. Bhuana Ilmu Populer. 